\section{Reflections of a Reference Librarian}

Susan J. Beck, 2009-10 President of the Reference and User Services Association, is Head of Public Services, Paul Robeson Library, Rutgers, the State University of New Jersey, Camden; e-mail: susan.beck@rutgers.edu. n this, my final column as RUSA President, I am taking some time to reflect on my career as a reference librarian. I guess you could say that I am probably in the declining years of my career. I am over fifty and have been a reference librarian since 1980-you do the math. So I wanted to reflect on some very basic questions, such as why did I became a reference librarian? what or who have been my greatest influences? and of course, what is the future of reference?

\section{THE MOST FREQUENTLY ASKED QUESTIONS一REDUX}

I have worked in the same library for twenty-seven years. When I first started, I told my students in my classes that there were three questions asked most frequently in the library. So, to relieve their suspense, I would just tell them the answers.

1. Where is the pencil sharpener? (At the circulation desk.)

2. Where is the photocopier, and how much do the copies cost? (In the front lobby, and 5 cents.)

3. Where are the restrooms? (Go downstairs, turn left and left again.)

Today, my most frequent questions are almost the same. The pencil sharpener question has been replaced by users needing assistance with printers. I still get asked about the photocopier costs, but the answer is more complicated: currently 15 cents after purchasing a copy card (40 cents) with a single dollar bill. The bathroom question and answer remains the same. After reading Lorraine J. Pellack's recent RUSQ editorial, First Impressions and Rethinking Restroom Questions, and the comments that her article generated on the RUSQ website (www.rusq.org) I agree that a polite, friendly, and quick response to this question is essential to forming positive impressions of your services. ${ }^{1}$

\section{WHY I BECAME A LIBRARIAN}

I became a librarian because I loved solitary studying in libraries while a college student. The library, as a place, was very comforting to me. As a child, I would go to the Norwalk Public Library - a Carnegie library-which still stands on Main Street in this Victorian town in Ohio. The library was right next to the A\&P grocery store, so when we went for 


\section{FROM THE PRESIDENT OF RUSA}

our weekly groceries on Friday evening, we also picked up new books. As I got older, I could easily ride my bike to the library. Then as a teen, when it was no longer socially acceptable to be seen riding a bike downtown, it was not too far to walk. Libraries were a familiar, comfortable, and safe place with so many interesting books! I could be easily attracted by different areas of the library, just as today I am so fascinated by searching the Web.

As an undergraduate at Eastern Kentucky University, I practically lived in the library. I was majoring in history, political science, and education, all areas where you had to write many papers. I went to the library for instruction classes, but I rarely asked reference librarians for help. In grad school, as a political science student at Miami University, I got my own carrel and set up shop. It was easy to live in that library because they had great vending machines in the basement where I would go to socialize, snack, and get right back to work. They had long hours too! As a grad student, I did consult the reference librarians, who were always friendly and helpful. I do not ever remember leaving the reference desk without knowing where I was going next. I was a happy and satisfied user.

Once I made my decision not to pursue a $\mathrm{PhD}$ in political science, I considered my options, and becoming a librarian just made so much sense. I loved to search for information and I loved being in libraries. So off to library school I went.

\section{THE CHALLENGES OF BEING A LIBRARY SCHOOL STUDENT}

Once I went to library school at Kent State, I also lived in the library; it was a satisfying habit by then. They too gave me a carrel and I sought out reference librarians for assistance. They were mostly friendly. Do you remember, however, the way you felt as a library school student asking questions of reference librarians when you were taking your first reference courses? You think that because you are going to be a librarian, maybe you should not ask questions of the real librarians? And when you do ask questions, you sometimes perceive that the librarians might just be a little testy about answering your questions because, after all, you are a library school student and shouldn't you already know how to answer your own questions? Why is there always that tension between library school students and reference librarians? I was recently asked this very question from a brand new library school student during a presentation at the School of Communication and Information at Rutgers University. I told the future librarian the following: "Please do ask the librarians as many questions as you can and on every occasion that you need to!" I believe that not only does this exchange provide the student with direction, but it also lets them observe the librarians' differing styles and approaches to discovering information. The reference transaction is a teaching tool, especially for those who will be doing the answering in the future.

\section{ON THE IMPORTANCE OF CATALOGERS}

I became a reference librarian because there was no other job I wanted more in the field. Being a cataloger was a contender, however. Today I still believe that you cannot be a good reference librarian without understanding the basic tenets of cataloging. I have a great deal of respect for catalogers. Once, while teaching a reference class in a library school, I was horrified to learn that cataloging was no longer a basic requirement. I proceeded to give my students a basic lecture on cataloging, subject headings, and different classification systems. They were even unfamiliar with the bright red Library of Congress Subject Headings, a tool I have always cherished. Today, even though we have cloud tags and metadata, you still must be able to tell users how to actually find a book on the shelf or the Web. I, for one, am not yet ready to abandon classification systems.

\section{WHO HAVE BEEN MY GREATEST INFLUENCES AS A REFERENCE LIBRARIAN?}

\section{The Early Years}

I suppose some of my first influences and perceptions about librarians came as a small child. I visited the library often and read many books, even getting a prize for reading the most books over the summer between fifth and sixth grade. The children's librarian, Carol Newton, was very tall, had a big smile, an extra loud laugh, and showed me the world of books. In junior high, I was elected the vice president of the library club and worked in the library. The librarian, Myra Carpenter, was caring, always very clever, and a wonderful inspiration. She could shush with the best. We kept in touch, and after library school she lent me copies of American Libraries to aid in my first job search.

\section{My Colleagues}

My greatest influences have been my colleagues. Early on, I was lucky to work with some very experienced librarians. My first professional job was at the Amelia Gayle Gorgas Library at the University of Alabama in Tuscaloosa. I worked with librarians from a mix of generations. I cannot begin to tell you the value of working with older, experienced professionals. They knew everything! I loved the commanding force of Vi Ayers when she would march poor unsuspecting students up and down the aisles and stacks of the reference room, following every possible lead. I also learned from Vi how to make light of a hearing disability: She just told everyone to speak up-they did not have to be quiet in her library. This lesson has come in very handy as I have aged. I loved Sally Reeves, our government documents librarian, who was tenacious and fearless in the face of the vast quantity of government information. It was Sally who told us all that the FBI had called to alert us to the possibility that we would be getting a visit 
from Russian spies. We went around for days wondering just what a Russian spy would look like.

When I changed jobs, and became a reference librarian at the Paul Robeson Library at Rutgers, the State University of New Jersey, in Camden, I fell in with another multigenerational group of librarians. In my library we have a rule that the library director works the reference desk so they understand what our users are doing. My first library director, Parker Worley, had a fabulous memory and was a great reference librarian. He not only seemed to know what was in most of the reference collection, but what was in our circulating collection as well. Jim Nettleman, then head of the Public Services Department, was someone I admired and would characterize as tenacious. He never left a stone unturned. It would really bother him if he could not answer a question. He was always the first person I went to if I was having trouble finding just the right source to answer a question. He was mentored by Worley, the director with the great memory. Reference was important in my library then. It was our shared belief that it was the most important activity of our librarians. It is great to work with a diverse group of individuals who can share their experiences and expertise. Now that I am on the other end of the age spectrum, I find it exceptionally beneficial to work with younger librarians. Disparate colleagues are the best support group.

\section{Actually Read Library Literature-Do You?}

I believe that much of the library literature I have read has also influenced me, but I wonder if I am unusual in this regard. When I asked my colleagues whether they had a favorite article, they often said no. I realize I may have developed a list of favorite articles simply because I have taught basic reference classes over the years and I have always been excited to try out new ideas. So, I will share a few titles with you.

One of the first articles I liked and ran across in library school was Benson and Maloney's "Principles of Searching." This article very simply describes the basic search steps when formulating a query. ${ }^{2}$ While perusing the Internet, I discovered it is still being used as required reading in some library schools.

I share Benson and Maloney's search steps with you here:

1. Clarify the question (the interview)

2. Establish search parameters (including amount and type of information desired, purpose, scope, time frame, geographical and language limits, etc.)

3. Identify sources to be searched

4. Translate the question into the language of each source

5. Conduct the search

6. Deliver the information

As a young librarian, back when I was called an "online searcher," I loved reading Carol Tenopir's "Online Database" columns in Library Journal. Today I still love running across any of her informative articles about searching or databases; they seem so comforting because she has been a constant in my professional life.

Another favorite article is Dewney and Michell's "Oranges and Peaches: Understanding Communication Accidents in the Reference Interview." 3 This article describes communication accidents that transpire during the reference interview. The example is given when a student asks for a book on oranges and peaches and they are really looking for is Darwin's Origins of the Species. It is an excellent overview of a common problem. If you have never read this-you need to!

I have always enjoyed Dave Tyckoson's sense of humor along with his practical, down-to-earth advice. You can easily do a search in H. W. Wilson's Library Lit or-dare I say it-Google (but only if you use Google Scholar) to come up with examples of Dave's wit. Among my favorites are his RUSA president's columns in volume 47 of RUSQ as well as "On the Desirableness of Personal Relations between Librarians and Readers: The Past and Future of Reference Service," in Reference Services Review. ${ }^{4}$

\section{RUSA Guidelines and the Definition of Reference}

The single professional document that I find most helpful to reread annually is RUSA's Guidelines for Behavioral Performance of Reference and Information Service Providers. ${ }^{5}$ After I read it, I find that I feel virtuous and ready to be the best reference librarian I can be. It is like taking a shower and getting rid of all those impurities that have snuck in over time. I can begin anew. You too should try rereading this if you haven't in awhile: It is on the RUSA website (www.ala.org/ rusa) under "Resources for Librarians." While you are there also look at the other fabulous guidelines that RUSA members have developed. Maybe there is something else there that will refresh and revive you. RUSA has so much to offer librarians. Another RUSA document that you should be sure to look at is the relatively new definition of reference created by RUSA's Reference Services Section. ${ }^{6}$

\section{Professional Development}

The single most influential workshop I ever attended was a three-day workshop presented by Ralph Gers for the South Jersey Regional Library Cooperative called "Better Communication Equals Better Reference Performance." This workshop was originally developed after Ralph Gers and Lillie J. Seward (Dyson) conducted a statewide survey in Maryland to determine to what degree a user is likely to receive a correct answer at the reference desk. The results that users received a correct answer only 55 percent of the time shocked the library world. The bottom line of the workshop was that we were told to ask each user at the conclusion of the reference interview, "Did I completely answer your question?" If the answer was no, you started over again until the user perceived they had received the correct answer. Pretty powerful stuff! We practiced and 


\section{FROM THE PRESIDENT OF RUSA}

practiced and practiced our skills over the three days. I am a better reference librarian because of this! ${ }^{7}$

There was another professional development experience that had a profound impact on my career. When I first started my job at the University of Alabama, the head of the Reference Department selected two of us to attend a weeklong training program at the University of Pittsburgh to learn to use the Dialog Query Language. Pittsburgh had a Dialog emulator as part of their library school and provided in-depth instruction on every aspect of how to search Dialog. This was an important skill to have in the early eighties, when we were still paying hefty online hourly charges to search individual databases. We started our workshops each morning at 8:00, and we were still doing searches at 10:00 each evening. Needless to say-I simply fell in love with online searching! I was a whiz at quickly connecting acoustic couplers and developed a natural rhythm attuned to the speed of the terminal. I imagine many of you might not have the slightest idea of the mechanics I am talking about, but boy it was so cool! Or maybe I should use the word "awesome"?

The thing that I hope any administrator will take away from these reminiscences is that it is extremely important to support skill development in young professionals. Provide them with opportunities to grow! Help them shine! I believe that experienced librarians need support for developing new skills too, whether they attend a conference or a local workshop. Don't stop the support after the tenure decision! We all need continuous rejuvenation!

As long as I seem to think I am imparting wisdom, I want to share with you something important I have learned as a professional. This may be a cliché, but make it a personal professional goal to invest in yourselves. Even if your library cannot afford to send you to conferences or other professional development opportunities, budget some of your own money every year and go. This action demonstrates your commitment to the profession and provides an opportunity for you to learn something new and network with individuals with similar interests.

\section{Influence of Being a Member of RUSA and ALA}

My active participation in RUSA and ALA has offered me many opportunities to engage in work that I would not have otherwise been able to do in my library. I first attended the ALA Annual Conference in New York City at the conclusion of library school in 1980. My main goal of course was to look for a job using the placement service. It also was my first experience with exhibits, and I must admit I was overwhelmed.

In my first job, at the University of Alabama, I was encouraged and financially supported to attend ALA conferences, and as an online searcher I gravitated toward the Machine-Assisted Reference Section (MARS). I discovered that you could volunteer for tasks even if you were not a committee member. So I attached myself to the MARS Measurement and Evaluation of Online Services Committee, where I went from being an intern to eventually chairing the committee. What was really important for getting committee assignments in those days was attending meetings and getting your name on the committee attendance list as well as expressing your interest to the chair. Today, you need to fill out an online committee volunteer form just after the ALA Midwinter Meeting (you can find it on the RUSA website under "About RUSA"). It still does not hurt to contact both the current committee chair and the appointing officer to express your interest.

Early in my career, as part of my MARS committee work I was involved in writing several guidelines relating to online searching. Later, as a member of what is now the Reference Services Section (RSS) Management of Reference Committee, I was fortunate to collaborate in the development of the revised edition of the Guidelines for Behavioral Performance of Reference and Information Service Providers. ${ }^{8}$ These guidelines are often used as part of training programs in many libraries and as a resource in many introductory referenceservices courses in library schools. I am very proud of the work I have done as a RUSA committee member.

In selecting committees for participation, I have always researched the committee first to make sure that it was indeed an active and productive working committee focusing on issues in which I was interested. I have always believed this was a good approach, but I recently heard Camila Alire, the current ALA president, say that she often tried to get appointments to committees to develop expertise in new areas, and I think that is a good approach as well.

I have always loved being on award committees. I have been on the Isadore Gilbert Mudge Award Committee, which selects an individual who has made a distinguished contribution to the field of reference librarianship. I have also been on the Reference Services Press Award committee, which selects the most outstanding article published in RUSQ over a two-year period. This committee obviously forces you to keep up with the current reference literature. It also is such a pleasure to eventually interact at the awards ceremony with Gail Schlachter, the award donor. It was wonderful to serve on both of these committees. As chair of the committee you get to notify the winner, and let me tell you, calling someone up and telling them they have won an award of $\$ 2,500$ or $\$ 5,000$ is a fabulous experience-better than giving gifts at Christmas!

\section{WHAT ABOUT THE FUTURE OF REFERENCE?}

This seems to be a topic that almost all RUSA presidents get to at some point in their columns. But since I am running out of space, I will give you the short version of my vision.

I believe one of the most significant challenges facing our users today is the need to sift through mountains of information. Some users, however, are simply happy just to select the top few hits in a Google search.

When you think of all that information, how can you not believe that there is a future for a profession that efficiently 
and effectively links users with the information they are seeking?

A couple of years ago, I was asked to give a presentation on the future of reference. While doing my research, I ran across a 1990 article in Library Journal by Margaret Steig (the 2008 Isadore Gilbert Mudge Award winner), which put this issue in perspective for me.

Few scholars, professionals, or average citizens care to acquire the expertise necessary to solve their own information needs; they did not before the library was automated, and they do not now. . . . Most users still need personalized guidance. ${ }^{9}$

Now doesn't that make you feel confident and more secure in your chosen profession? Julie Still, a witty Rutgers colleague, quipped to me on this topic: "People can learn to change the oil in their car and cut their hair-but do they?"

Taking that point of view, I believe the future of reference is safe!

\section{MY HOPES FOR THE FUTURE OF RUSA AND FAREWELL}

In looking back over this past exciting year, it has been an honor to be your president. I have enjoyed working with each and every one of you. You are all truly amazing! I was fortunate to have a group of other great RUSA presidents past and future with whom to work, including David Tyckoson, Neal Wyatt, and Barry Trott. Each individual brought their special strengths to the table, and for that I am appreciative. I have learned something from each of you. I have also enjoyed working and getting to know our new executive director, Susan Hornung, who gets me, and for that I am sincerely grateful.

This experience has provided me with a brief view of how ALA works. I respect our leaders, and I value the significant contributions of both RUSA and ALA to our profession. Thank you all so much for your support and guidance when I asked for help.

Now we must look to our future. In the coming year I hope to see RUSA providing a variety of professional development opportunities on the Web, such as chat discussions and webinar offerings. I hope to see our website continuously develop and provide new content by our committees participating in the Five Things a New Librarian Should Know About initiative. I have only the best wishes for the success of RUSA. I hope you will continue to participate in RUSA, the foremost organization of reference and information professionals. I hope I will be reading your columns here in the future.

If you read this column, please e-mail me and let me know. In the subject line simply put "I read your summer column." Please send it to me at susan.beck@rutgers.edu.

\section{References and Notes}

1. Lorraine J. Pellack, "First Impressions and Rethinking Restroom Questions," Reference \& User Services Quarterly 49 (Fall 2009): 4-6.

2. James Benson and Ruth Kay Maloney, "Principles of Searching," RQ 14 (Summer 1975): 316-20.

3. Patricia Dewney and Gillian Michell, "Oranges and Peaches: Understanding Communication Accidents in the Reference Interview," RQ 35 (Summer 1996): 520-23, 526-36.

4. David J. Tyckoson, "On the Desirableness of Personal Relations between Librarians and Readers: The Past and Future of Reference Service," Reference Services Review 31, no. 1 (2003): 12-16.

5. RUSA Management and Operation of User Services Section, Management of Reference Committee, "Guidelines for Behavioral Performance of Reference and Information Service Providers," Reference \& User Services Quarterly 44 (Fall 2004): 14-17, www .ala.org/ala/mgrps/divs/rusa/resources/guidelines/guidelinesbehav ioral.cfm (accessed Dec. 20, 2009).

6. RUSA Reference Services Section, "Definitions of Reference," www .ala.org/ala/mgrps/divs/rusa/resources/guidelines/definitionsrefer ence.cfm (accessed Mar. 10, 2010).

7. Ralph Gers and Lillie Dyson, "I Heard You Say ... Peer Coaching for More Effective Reference Service," Reference Librarian no. 22 (1988): 245-60. See also Ralph Gers and Lillie J. Seward, "Improving Reference Performance: Results of a Statewide Survey," Library Journal 110 (Nov 1, 1985): 32-35.

8. RUSA, "Guidelines for Behavioral Performance of Reference and Information Service Providers," www.ala.org/ala/mgrps/divs/rusa/ resources/guidelines/guidelinesbehavioral.cfm (accessed Mar. 10, 2010).

9. Margaret Stieg, "Technology and the Concept of Reference; Or, What Will happen to the Milkman's Cow?" Library Journal 115 (Apr. 15, 1990): 49.

\section{FROM THE EDITOR CONTINUED FROM PAGE 304}

fascinating professional books for inclusion in "Sources" in her role as editor of the professional materials section. Distinguished reviewers of professional materials include Jenny Stenis, Larry Cooperman, Katy Herrick, Anthony Stamatoplos, Bernadette Lear, Lisa Powell Williams, Melanie Wachsmann, Robin Sinn, and Sarah Hart.

Since this is a division journal, there are a great many other people who contributed to the journal's success this past year. Susan J. Beck never failed to deliver interesting and thought-provoking presidential columns on schedule. Several RUSA sections and committees used the journal to highlight their best work. Finally, Susan Hornung patiently answered my many questions relating to the budget and other issues while learning on the job during her first year as RUSA's new executive director. 